in the various sections are treated. The language is clear, the illustrations are good, and the references are very satisfactory. The work is admirably suited for the dresser or practitioner on matters relating to minor surgery, wounds, hip disease, emergencies, and other subjects likely to come under his notice. The appendix contains a useful formulary.

Yellow Fever. A Monograph by James W. Martin, M.D. (Edinburgh: E. and S. Livingstone.)-This little work, appropriately bound in yellow and black covers, adds nothing to our knowledge of yellow fever. If we wrong the author in saying so he has himself to blame, for he expresses his meaning so badly, that in many places we are quite unable to make it out. This obscurity may be of no great consequence in those parts of the work referring to symptomatology, pathology, diagnosis, and so forth ; but an author who allows such a sentence as the following to appear incurs a grave responsibility. Referring to the treatment of yellow fever by turpentine, Dr. Martin says:-"Given internally combined with oil and applied externally as well, it is found of great effect the dose is 20 minims to 1 ounce." Does this mean that we may give this powerful drug in 1-ounce doses in a disease of which albuminuria and suppression are prominent symptoms; or does it mean that the dose of the turpentine is 20 minims, and that it has to be given in an ounce of oil ? We have failed completely to follow his account of the microscopical appearances of the liver in yellow fever. This and many other things in the book, including the temperature charts at the end, are to us quite unintelligible.

\section{REPORTS AND ANALYSES} AND

\section{DESCRIPTIONS OF NEW INVENTIONS} IN MEDICINE, SURGERY, DIETETICS, AND THE ALLIED SCIENCES.

MALT PASTILLES.

Messrs. Rowntree and Co., of York, have sent specimens of pastilles containing extract of malt. The manufacturers state that after a long series of experiments directed to the object of making a malt pastille in which the diastasic power of the malt extract should be retained, they have at last obtained a satisfactory result. Examination of these pastilles shows that the extract of malt which they contain is an active one, and we are of opinion that Messrs Rowntree and Co. have succeeded in making not only a very pleasant pastille but also one which possesses nutritious and digestive properties.

MISCIBLE LIQUID EXTRACT OF COCA.

THE liquid extract of coca of the British Pharmacopaia, when mixed with water, forms a thick repulsive-looking mixture. This objectionable feature of the British Pharmacopoia liquid extract is due to the fact that by the official process the chlorophyll and wax are extracted, and these are precipitated by the addition of water. We have received a specimen of miscible liquid extract of coca prepared by Messrs. Wright, Layman and Umney, 50, Southwark Street, London, S.E., in which the chlorophyll and wax are eliminated without in any way affecting the aroma or alkaloidal value of the extract. This fluid extract is perfectly miscible with water, and forms a bright transparent liquid possessing the characteristic aromatic odour and taste of the coca leaf. This preparation appears to be a considerable advance in the pharmacy of coca.

\section{FLUIDE-COCA AND CUCA CHOCOLATE.}

$\mathrm{We}$ have received from Messrs. Henson and Co., Beulah Hill, London, S.E., a specimen of a fluid extract of coca which is stated to be prepared from an extract of the fresh coca lea made in Peru. The object of the manufacturers appears to have been to obtain a concentrated fluid extract of coca, which should combine all its principles without those non-essential matters, such as chlorophyll and wax, which render the ordinary liquid preparations of this drug so unpleasant to take, and which are asserted to be the cause of the indigestion and nausea occasionally produced. Our examination of this extract shows that it is a highly concentrated preparation, and that it contains those principles upon which the medicinal activity of coca depend. It is a glycerine solution, and does not contain any alcohol. Fluide-coca will be found a very portable and agreeable form of coca ; it is also convenient for the preparation of coca wine. Cuca chocolate is a combination of the extract of fresh coca leaves with chocolate. It is very palatable, and can be relied upon to possess the full medicinal properties of the drug.

\section{MALTA-RICINAL}

THIs preparation is made by Messrs. Kingsford and Co., 51, Piccadilly, W. It is a well-made mixture of equal parts of Italian castor oil and extract of malt. It has a pleasant flavour, and we are unable to perceive any odour or taste of the castor oil. It appears to be readily taken by patients, and does not produce unpleasant eructations.

\section{GALEN.}

[A Bibliographical Demonstration in the Library of the: Facolty of Physicians and Surgeons of Glasgow, DeCEMBER 9TH, 1891.]

By JAMES FINLAYSON, M.D.,

Physician to the Glasgow Western Infirmary and to the Royal Hospital for Sick Children, Glasgow ; Honorary Librarian to the Faculty of Phy sicians and Surgeons of Glasgow, etc.

(Concludec', from $p$. 731.)

Galen as an Expert in Diagnosis.

Galen's strongest point in diagnosis turned on his discrimination of the different kinds of pulse. On account of his wonderful skill in this way, it was said that "Apollo prophesied by the mouth of Galen." 9 Full justice is done to him by M. Ozanam and by Dr. Broadbent, in their treatises on the pulse. The latter has furnished a translation of a large part of the Libellus de Pulsibus ad Tirores. ${ }^{10}$ The following short. extract, selected from his translation, may suffice to show the style of the author:

[Pulse.]-Chapter II. The artery will seem to the touch to be distended in every dimension. There are three dimensions in every body-length, depth, and breadth.

In an animal in a normal state of health you will find the artery quite moderately distended; but in normal conditions sometimes the tension is too low, sometimes too great in every dimension. Now you must remember what a normal pulse is like, and if you find an abnormal pulse of excessive breadth, you should term it "broad"; if of excessive length, "long"; and if of excessive depth, "deep"; and in like manner the opposite of these " narrow," "short," and "shallow." And a pulse that is in all these dimensions abnormally diminished is termed "small," and one that is abnormally augmented "large." Such, then, are the varieties of pulse, as far as dimension goes.

Chapter III. As regards special characteristics, there is swiftness and slowness. In the former case the movement is free and unrestrained, in the latter case enfeebled. These conditions you must judge by comparison with the normal.

The strength of the pulse, or the reverse, is determined by the force with which it repels the touch; if it repels violently it is strong, if weakly the reverse.

And there are variations in the softness or hardness of the arterial coat; it is soft when the artery appears, so to speak, flesh-like to the touch; hard when it seems dry and hard, like leather.

So then you notice differences in pulses such as this at once, as you observe the movement of the artery, though they are not, however, specially characteristic of it, as were the three before mentioned.

His writings on the pulse are very extensive, and a large part of both Vols. viii and ix, in Kühn's edition, is taken up with the different treatises on this subject. At pp. 505 and 532 of Vol. viii, and at p. 438 of Vol. ix, I show you his elaborate tabulation of different kinds of pulse-twenty-seven varieties, each of these divisible into three varieties, or eighty-one in all.

\footnotetext{
9 Ozanam. La Circulation et le Pouls; Par is, 1836, p. 21 10 Broadbent, The Pulse ; London, 1890, pp. 6-11.
} 
The following illustration of Galen's diagnostic skill in pulses shows likewise his pertinacity, and his acuteness in other things as well as sphygmology!

[Diagnosis of Love by the Pulse.]-Some medical sophists, ignorant of the way in which Erasistratus discovered the love of a young man for his father's maid, in asserting that he had discovered it from feeling love pulses in the young man, allege, indeed, nothing more than anyone might say, namely, that it was found out 'from the pulse. I am certainly not able to say in what way Erasistratus may have made the discovery, but I will disclose in what way I did so. I was called to visit a woman [the wife of Justus] who was troubled with insomnia, and was tossing about from one position to another on a couch. On ascertaining that she was free from fever, I made some inquiries in regard to the particulars of the onset of the condition, from which I might form a notion of how the insomnia was caused. But the woman herself, if she made any response at all, made it to little purpose, showing that it was vain to question her further; at last, with averted looks, she covered herself up entirely with the bedclothes, and lay with her head turned away on a small pillow, after the manner of a person in need of sleep. Therefore I left, and from these things concluded that she was sutlering from one of two things-either that she was the victim of melancholia, or that she was affected by some grief which she was unwilling to avow. Therefore I delayed till next day to examine her with greater care; and on my arrival, the first thing I heard, from a maid standing by, was that I could not see her. On my next visit I was told the same thing. I returned a third time, and the servant told me, in order that I might go away, that the woman did not wish to be disturbed. When I ascertained that on my departure she had made her toilet and resumed her accustomed ways, I went to see her next day, and in a general gossip with the maidservant I ascertained that she was clearly troubled by some distress, the nature of which I found out by accident, in the same way as I think Erasistratus also made his discovery, accidentally; for when I had made sure that she suffered from no bodily affliction, it happened that, at the same time as $I$ was visiting her, this was confirmed by some one coming from the thes.tre and mentioning that he had seen Pylades dancing. Her look and colour underwent a change ; the brachial pulse, which I was holding, became irregular and suddenly agitated in several ways, the sure index of mental emotion; the same thing thappens in those who are contending about something. On the next day, I directed one of those who followed me, that when I went in on my visit to the woman, he was to come in shortly after, and mention that Morphus was dancing to-day. This was done, but I found no disturbance in the pulse. In a similar way, on the following day, I had taken care that the name of a third dancer should be mentioned, but there was no alteration of the pulse. On the fourth evening; I made a careful experi. ment. With the pulse in my hand, it was again mentioned that Pylades was the dancer; again there was the same agitation, and I concluded that the woman was in love with Pylades, a diagnosis confirmed by the repetition of the experiment on subsequent days (Kühn, vol. xiv, p. 630 ; com pare also vol. xviii B, p. 40).

On the title page of the Latin edition published in Basle in 1562, this story is depicted-"Amantis Dignotio"-the woman in bed, the husband, Justus, standing by, Galen feeling the pulse, and a "Nuntius" intimating the name of the dancers.

Galen's diagnosis of the illness of a Sicilian physician was supposed by the patient and his friends to be based on the pulse; but, as will be gathered from the amusing narrative, this part, although important, was trivial as compared with the acuteness of observation which utilised every trifling circumstance which could be laid hold of. The following is rendered into English from Daremberg's French translation (tome ii, p. 657).

[Wonderful Diagnosis of the Case of a Bicilian Physician by Galen.]When I came to Rome for the first time I was greatly admired by the philosopher Glaucon on account of a similar diagnosis. Finding me on the road, he said to me that $I$ had arrived opportunely; then taking $m$ hand, he said: "We are quite near an invalid whom I have seen just now, and I wish you would come to visit him with me. He is a Sicilian physician whom you have seen a few days ago walking with me." "What is the cause of his illness ?" I said. Placing himself at my side, he said very frankly and plainly-for he was not one to cheat or play tricks"Gorgias and Apelas informed me yesterday that you have made diagnoses and prognoses which approach to divination rather than to the art of medicine. I desire, then, to have a proof, not of your knowledge, but of the power of the art of medicine, and to ascertain if it can furnish such an astonishing diagnosis and prognosis." During this conversation we had arrived at the door of the patient, so that I had not been able to reply to his request, nor to tell him, what you know I often repeat, that sometimes there are, fortunately for us, indubitable signs, but that some- times everything is doubtful, and that consequently we have to await the results of a second or a third examination. At the outer gate we met a domestic who was carrying from the sick room to the dunghill a vessel containing excrements resembling the washings of flesh-that is to say, thin and bloody fluid, a constant sign of an affection of the liver. Without appearing to have noticed anything, I went with Glaucon to the physician, and I was putting my hand to his arm, wishing to know if there was inflammation of the organ or simply atony. The patient, who was himself a physician, as I have mentioned, said that he had just returned to bed after having been at stool. "Consider, therefore," he added, "that the frequency of the pulse is increased by the effort I have made in rising." Thus he spoke, and as for me, I ascertained in the pulse the sign of inflammation. Then, seeing placed at the window a pot containing hyssop prepared with honey-coloured water, I bethought me that the physician believed himself affected with a pleurisy, on account of feeling at the false ribs the pain which sometimes also appears there in inflammation of the liver. I thought that, as he experienced this pain, his respiration was frequent and small, and that he was tormented with short paroxysms of cough; in a word, he believed himself affected with pleurisy, and so had made a preparation of hyssop and honey water. Recognising, then, that good fortune had given me the means of raising myself in the estimation of Glaucon, I placed my hand on the false ribs on the right side of the patient, and indicating the place, I said that he suffered in this region. The patient confessed it, and Glaucon, believing that the pulse alone had sufficed for this diagnosis of the affected place, showed visible signs of admiration. To astonish him further, I added, "If you have admitted that you suffer there, acknowledge also that you experience the necessity of coughing, and that at pretty long intervals you are seized with a short, dry cough, without expectoration." As I said these words he coughed, by chance, exactly in the way I had indicated. Then Glaucon, astonished, and being unable to contain himself, heaped on me wellearned praise, with a loud voice. " Do not suppose," said I, " that these are the only things which Art can divine regarding patients; there are others which I will mention. The patient himself will be my witness.' Then addressing him: "When you breathe more deeply, you feel a sharper pain at the plane which I have marked; you experience also weight in the right bypochonder." At these words the patient could not restrain himself; full of admiration he joined his exclamations to those of Glaucon. Recognising the success which I had obtained on this occasion, I wished to risk a word about the twinges at the clavicle; but although knowing well that this accompanies grave inflammation of the liver, as scirrhus, I did not dare to advance this, fearing to compromise the praises which they had lavished on me. I had the idea of sliding in this remark, with precaution, and turning to the patient I said: "Shortly, you will experience twinges at the clavicle, if you have not already felt them." He confessed this to be the fact; and I said, looking at the patient, who was struck with astonishment, "I will not add further to my indications than this divination; I will announce the opinion which the patient himself has formed of the disease with which he has been affected." Glaucon said that he did not any longer despair of this divination; and the patient, stupified by this singular promise, gave me a piercing glance, and close attention to my words. When I had told him that he believed himself affected with a pleurisy, he acknowledged the fact, testifying his admiration; and not he only but also the servant who came to make the affusions of oil as if he had a pleurisy. Glaucon since this time conceived a high opinion of me and of the medical art, which he had esteemed but slightly before, never having found himself associated with remarkable men who were consummate masters of the art. (Kühn, vol. viii, p. 363).

This story is also depicted in the title page of the Latin edition, Basle, 1562, "Hepatici Cognitio." We see the patient in bed; "Glauco " standing by ; Galen applying his hand to the region of the liver; and a servant is seen, through an open door, emptying a vessel into the dunghill.

A better insight into Galen's really scientific methods of diagnosis may be gained from his treatise De Locis Affectis; indeed, in several passages, one might almost think he was reading a modern treatise on medical diagnosis. I have selected the following extract from this treatise as to the diagnosis of urinary disorders. It is rendered from Daremberg's French translation (tome ii, p. 471).

[Differential Diagnosis in Urinary Disorders.]-Another kind of diagnostic is drawn from certain signs which manifest themselves when something abnormal is enclosed in a region with which it has no natural relation-for example, a stone in the kidneys or bladder, or pus in the thorax. To this variety may be referred a clot of blood, whatever may be the place where it is enclosed, or any peccant humour engendered in the body of the animal, or introduced from without. This fact has raised among many modern physicians a question, useless indeed for practical purposes in medicine, but giving rise to speculative views. They have 
asked themselves if such abnormal things, engendered in us, come under the category of " affected places;" or if, no place being affected, the animal suffers solely from the presence of this unnatural cause. That such a problem is useless, as I have said, is easily recognised in considering how much diagnosis contributes to practice. Thus, suppose there is a person who has for three days passed absolutely no urine, would we not immediately inquire in which part of the body the cause of mischief is ? Is it in the kidneys, in the ureters, in the bladder, or in the urethra? Certainly we would not search in the liver, the lung, the spleen, the stomach, the lieart, nor in any other part, because not one of these is a urinary organ; but if we did not know that the secretion of urine takes place first of all in the kidneys, then that the uriue passes through the ureters to the bladder, and that it is evacuated from it in the manner that we have indicated in the discussions. On the Natural Faculties (1, viii), we could not discover anything from this. It is not even enough to go this length, for it is preferable to search, among the causes announced, for what may be the cause of the retention of urine.

Here is the method to follow in this inquiry : to inquire into all the symptoms present and past, examining for one's self the symptoms actually present, and ascertaining the past symptoms, not merely from the patient but also from the attendants (see Hippocrates, Aphor., 1, i). Is there, for example, a tumour in the region called pubic-a tumour indicating clearly that the bladder is full to a certain extent, and that the discharge of urine is completely suppressed is it not evident either that the force which presses the urine out is abolished, or that the passage of the urine is obstructed ? But one will examine next if this force can be abolished, recollecting how the evacuation of urine is effected in healthy persons, who possess voluntary control, the muscle which surrounds the neck of the bladder ceasing to act, while the bladder itself acts. The action of the muscle depends on our will, that of the bladder is involuntary and physical. In fact we have shown in our commentaries On the Natural Faculties, that in almost all parts of the body there exists a faculty for separating superfluities, a faculty which all animals constantly possess, and of which they make use when hampered by these superfluities. When then this faculty has been injured, there results sometimes the affection named ischuria. But if you placed the patient in such a position that the neck of the bladder inclines downwards, pressing with your hands on the abnormal tumour, the urine will be expelled. If this attempt leads to no result, the idea of paralysis must be abandoned, and we must suppose that the urethra is obstructed. In fact, the paralysis of the muscle which surrounds the urethra produces not ischuria but involuntary discharge of urine. [Kühn, vol. viii, p. 7.]

[Galen then goes on to describe, in similar detail, what kinds of obstruction in the urethra might cause retention of urine. He supposes the case of a child who had symptoms of stone previously; such a case is to be further explored by a catheter, pushing away the stone from the neck of the bladder, and so giving passage to the urine; and so on with other causes of obstruction, by clots, etc.]

Galen's recognition of jaundice as caused by snake bites is interesting as a clinical description. The following is rendered from Daremberg's French translation (tome ii, p. 654).

[Jaundice from Snake Bites.]-One of the slaves of the Emperor [Marcus Aurelius] whose duty it was to drive away snakes, having been bitten, took for some time draughts of ordinary medicines, but as his skin changed so as to assume the colour of a leek, he came to me and narrated his accident; after having drunk theriaca he recovered quickly his natural colour. Physicians seek to find out if there are signs peculiar to poisoning, because they often see, without the administration of any deadly poison, that the body presents a corruption of the humours similar to that which is produced by poisons; it is not at all surprising, therefore, that there sometimes supervenes a change in the humours, so that the whole body is affected with jaundice. [Kühn, vol. viii, p. 355].

A picturesque synonym for diabetes, from the diagnostic

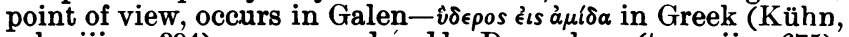
vol. viii, p. 394) ; or, as rendéred by Daremberg (tome ii, p.675), hydropisie dans le pot de chambre. His definition of inflammation, as given in Gale's translation, p. 126, comes very near the words which have become stereotyped in medicine.

[Inflammation.] The Grecians use to call that an inflammation, which cometh with great tumor or swelling in the fleshie parte, strained and stretched forth, resisting with pulsation and dolour, hot and red. (Kühn, vol. vii, p. 707.)

The following short note about aneurysm may also be quoted here from Gale's Translation, p. 131 :

[Aneurysm.] When there is an orifice made in the arterie, that affect is called Aneurisma, and it chaunceth when the arterie being wounded, the skin which is above commeth to a ciccatrise, but the separation which is in the arterie remaineth, being neither conglutinated, nor brought to a ciccatrise, neither yet stopped with flesh. These affects are chiefelie knowen by the pulse and beating which the arteries doe make. And also all the tumour vanisheth awaie when the arterie is pressed downe, the substance which made the tumour, runneth backe againe into the arterie, when it is so compressed downe. (Kühn, vol. vii, p. 725.)

\section{Galen as a Practitioner.-Bloodletting.}

The theoretical principles underlying Galen's practice have been already alluded to, but it may interest some to hear that as far back as Galen we have a clear enunciation of the principles of cure per similia as well as per contraria; many of the public foolishly think that the former principle was originated last century, although long before universally recognised.

[Per similia et per contraria.] "Ac si preter naturam sit quod indicet, contrarium id semper indicare: sin secundum naturam se habeat non contrarium sed simile." (Kühn, vol. $x$, p. 775.)

On the great question of blood letting, the following short extract given by Dr. T. K. Chambers in his racy paper, mentioned in the first footnote, may suffice at present.

[Blood letting.] Next there was a fourth patient, a woman, who was ill at the same time that the catamenia were suddenly stopped, whom these enemies to bleeding ${ }^{11}$ brought to death's door. They kept herfor three days absolutely without food because she had a continued fever; on the fourth day they gave her the smallest possible quantity of slops; on the fifth they ordered fasting again, and then she got violently delirious, jumped up, and ran screaming about out-of-doors, and the attendants had great difficulty in restraining her violence. She, however, was saved by Nature, through a copious effusion of blood from the nostrils. This was a circumstance which should excite our admiration, and at the same time teach us what a powerful influence bloodletting has in such affections, for immediately after the hæmorrhage from the nostrils the woman was freed from all her symptoms. Now, previously to this I had shunned having any communication with the medical men, guessing what they would say against the use of venesection. But since it was so very clear to all that the woman's life was saved by the evacuation of blood, I recalled to their memory the fatal cases [already narrated in the passage] expressing an opinion that perhaps those, too, would have been saved if they had been bled, and I gave sundry reasons for it. But these gentlemen involved the matter in a maze of words, twisting the argument round and round and up and down, came to no conclusion. However, they at last ended by taking refuge in Erasistratus, stating that it was "shown by him in his First Book on Loss of Blood, that it was better to apply ligatures to the limbs than to bleed" (Kühn, vol. ii, p. 190).

\section{Galen's Use of Medicines.-Theriaca.}

Regarding the use of special medicines by Galen I must. refer to Dr. Gasquet's article, indicated in the first footnote, where many interesting details and references on this subject may be found; but I cannot pass over the great remedy called "Theriaca." For compounding this Galen had a great reputation. This word theriaca (from which our word treaclecomes, from a superficial resemblance between them) is de-

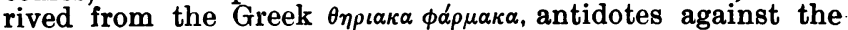
bites of wild beasts - from $\theta \eta i_{i} o \nu$ and $\theta r_{1} \rho$, a wild beast. Originally devised as an antidote to such bites, it came to be used, in certain of its forms, as an antidote to other poisonings, ${ }^{12}$ to which important people were specially liable; and from this the term came to be applied to remedies regarded as antidotal to disease (compare the passage already quoted on jaundice from snake bites). Opium was probably the most. important ingredient in many, if not all, the forms of theriaca, and powdered snakes may be regarded as the most striking, from the point of view of curing per similia! The number of ingredients varied, but was always enormous; even in this modern French Codex (1866), which I show you here, the ingredients of " thériaque " number 57, including, strange as it may seem, not only "opium de Smyrne," but also "vipères sèches"! Galen informs us that not a few, and among them the Emperor Marcus Aurelius himself, took a daily dose of theriaca as a precaution or antidote. ${ }^{13}$

Galen as a Teacher.-Profession in Rome.

Galen Was distinguished as a teacher as well as a practitioner; indeed then, as now, reputation as a teacher assisted

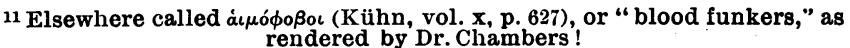

12 Omnino a lethalibus et deleteriis appellatis medicamentis erit securus et immunis" (Kühn, vol. xiv, p. 3).

13 Ad Pisonem de Theriaca, Kühn, vol. xiv, p. 216 ; see also vol. xiv, p. 3. 
in gaining practice, perhaps even more so at that time, as the lectures and the displays of surgical operation seem to have been of a more public nature. Puschmann says of Galen: "In order to become known there [in Rome] he gave public lectures on ject, and the practical knowledge of the lecturer, soon attracted a ject, and the practical knowledge of the lectues, of the most distingumerou circles of the capital. Amongst his hearers were men in inguished circles of the capital. Amongst his hearers were men in inDamtial positions, such as the philosophers Eudemus and Alexander of Damascus, the prefect Sergius, the consuls Boëthus and Severus, who Lucius.'4 In this way Galen succeeded, within a short time, in obtaining a profitable medical practice." (History of Medical Education, London, 1891, p. 95.)

In the quotations already given about tying the aorta, we have a glimpse of his influence on his pupils in their ardour in trying to convict of incompetence a rival teacher who had different views from their master. We likewise get an indication of his clinical teaching in connection with the case of "Amantis Dignotio," for he there makes use as a messenger of one of his pupils, apparently-" ex iis qui sequebantur me"-showing that they visited patients with him at their own homes, and received in this way their clinical instruction. ${ }^{15}$ Of the state of the profession in Rome Galen draws a dreadful picture; but as he himself poses as the victim of the envy and persecution of the physicians there, it is perhaps fair to discount somewhat his retaliation on them in this abusive description. One can easily gather, even from the quotations I have given, that Galen had, as a French biographer phrases it, "un amour-propre excessif"; and his acrid disputes, with syllogisms embellished by such phrases as "tu stupidus es," might naturally set the profession there against him ; indeed, his position in Rome was probably only rendered safe by the influence of Marcus Aurelius and other potentates. Galen says of physicians in Rome :

[Medical Profession in Rome.]-They will say or do anything to curry favour with the multitude; they will also flatter and favour; in the town they will daily salute wealthy and influential persons, walk alongside of them, take them to their houses, give banquets, and behave themselves like buffoons. Others, not only in this manner, but also by the gaudiness of their clothing and their rings, by the splendour of their silver vases and by the troops of followers accompanying them, endeavour to dazzle fools and show that they are persons of tremendous importance and men to be imitated. (Kühn, vol. xiv, p. 600.)

In another passage he draws a comparison between the members of the medical profession and robbers, the sole difference being, he says, that the former perpetrate their crimes in the towns and the latter in the mountains. ${ }^{16}$

Notwithstanding the hard lines which had, according to himself, fallen to his lot through the hatred and envy of the profession in Rome, Galen seems to have had at least one good fee, received from the Consul Boëthus for attendance on his wife ; he sent him 400 " aurei," equivalent, we may say. to 400 English guineas. Indeed, so far as the value of that coin can be estimated, the "balance of exchange" seems to have been in favour of Galen, for it is quoted in the Dictionary as $£ 1$ 1s. $1 \frac{1}{2} \mathrm{~d}$. ; but these " aurei " evidently acquired a very special additional value in Galen's eyes, as the rumour of them increased the envy of his fellow-practitioners and added to his praise! ${ }^{17}$

14 Some of these are figured and named, as viewing Galen's dissection of an animal, on the title page of the Latin edition, Basle, 1562.

25 Clinical instruction seems also to have been given in Tabernæ Medicx or Iatreia the construction of which was arranged to secure good light and ventilation. (See Puschmann : History of Medical Education, London, 1891, p. 111 ; also Galen : Kïhn, vol. xviii B, p. 678, 674, etc.)

16 "Sola hac re a latronibus differunt, quod in urbe, non in montibus facinora sua perpetrent." (Kühn, vol. xiv, p. 622.)

17 "[Boëthi uxorem uteri profluvio laborantem praeter spem aliorum sanat].......quadrigentos aureos ad me misit, auxitque generosorum horum medicorum invidiam, inde quod me laudibus extolleret." (Kühn, vol. xiv, p. 647.)

Dr. ERNst Schwimmer has been appointed Extraordinary Professor of Dermatology in the University of Buda-Pesth.

Drath onder Chloroform in New York.-The New Fork Medical Journal announces that a death under chloroform recently occurred in New York. The patient was a man, aged 55, with atheromatous arteries, who was about to undergo amputation of a finger for gangrene. The evidence given at the inquest showed that death had been caused by pulmonary œdema.

\section{IRISH DISPENSARY MEDICAL OFFICERS}

THE Chairman of the Parliamentary Bills Committee of the British Medical Association, Mr. Ernest Hart, had an interview with the Chief Secretary for Ireland, on Wednesday, on the subject of the grievances of Irish Poor-law medical officers. Mr. Jackson has agreed to receive a deputation of the joint Committees of the British Medical Association, the Irish Medical Association, the Royal Colleges of Surgeons and Physicians of Ireland, and the Irish Graduates Association, on this subject, in Dublin on Tuesday, April 19th, at 3 P.M.

Professor Billroth celebrates this month the twentyfifth anniversary of his appointment as Professor in the University of Vienna, and the fortieth of his graduation as Doctor of Medicine.

Successful Vaccination.-Mr. A. de Winter Baker, Public Vaccinator of the Dawlish District of the Newton Abbott Union, has been awarded the Government grant for successful vaccination for the third consecutive time.

THE need of providing a park and open space for the rapidly-increasing population of Tottenham and Wood Green, now numbering nearly 100,000 , has been recognised by the Tottenham Local Board. This body has resolved to purchase Bruce Castle and 20 acres of land. The price is $£ 15,000$.

Tнғ New York State Committee on Codes has agreed to report favourably on the Bill amending the Capital Punishment Act of the State. The Bill does away with electrocution, and substitutes hanging as the mode of exacting the death penalty.

The Etiology of Canckr.-M. Poncet, Chief Surgeon to the Hôtel Dieu at Lyons, makes an appeal in the French medical journals to all members of the profession who may have met with cases of interest as bearing on the question of the contagiousness of cancer to be good enough to communicate with him before June of the present year.

Infirmary Medical Superintendents' Society.-At the annual meeting of this Society, held at the Inns of Court Hotel on March 26th, under the presidency of Dr. D. M. Forbes, the officers for the ensuing year were elected, Mr. John Hopkins, F.R.C.S., being chosen President and Drs. $H$. E. Harris and A. H. Robinson being re-elected Treasurer and Secretary respectively.

Great Northern Central Hospital, Holloway Road, N. -It has been decided by the Cnmmittee of the Great Northern Central Hospital, Holloway Road, to erect the additional wing, which will complete the new buildings, as a memorial to the late President of the institution, the Duke of Clarence and Avondale. Tenders for the work have been accepted, the cost of which, with the necessary furniture and fittings, will amount to about $£ 30,000$.

Deaths in the Medical Profession Abroad.-Among the members of the medical profession in foreign countries who have recently died are Dr. Gustav Lehr, Director of the Bad Nerothal at Wiesbaden, aged 40; Dr. Milton Baldwin, formerly Coroner of Newark, New Jersey, U.S.A., and for some years surgeon to the Ward General Hospital of that city, aged 71 ; Dr. Karl Aberle of Vienna, Physician in Ordinary to the Empress Caroline Augusta, aged 74; Dr. Josef Zanchi, Ritter von Catto und Linchenberg, of Vienna, aged 67 ; Dr. Pippingsköld, Emeritus Professor of Midwifery and Diseases of Children of the University of Helsingfors; and Dr. W. A. Karawajeff, for fifty-one years Professor of Surgery in the University of Kieff, aged 81. Professor Karawajeff was a surgeon of the highest repute in Russia, and in 1844 he was presented with a diamond ring by the Emperor Nicholas after having successfully performed a difficult operation on Prince Golizyn. Among the honours conferred on him were the Order of the White Eagle, the Alexander Newski Order, and the Stanislaus and Ann Order (First Class). A street in Kieff now bears his name. Herr Joseph Leiter, the well-known instrument maker of Vienna, also recently died at the age of 62 . 